\title{
Wittlin Meets Death ${ }^{1}$
}

At first crack of dawn on Sunday, 29 $9^{\text {th }}$ February, 1976, Józef Wittlin slipped into eternal sleep in a New York hospital. Thereupon, in the words of the orator, as he stood before the Gates of Heaven he was greeted by Isaiah, Jeremiah and Ezekiel, and by the disciple beloved of the Lord, the Poverello of Assisi. And in this company he was led to the throne of the Almighty. Only the previous evening he had told the priest he was prepared for death, and would offer his life for the peace of the world.

During the month spent in hospital, Wittlin had chatted away in Italian with a charming nurse from Potenza. He sensed that he was dying but, as his widow Halina later wrote to a friend, "we deluded him with our lies into believing he would somehow recover and continue writing. But that was not to be." His brain was as alert as ever, and he remained conscious until the end, conversing with Halina into the early hours. His last moments were peaceful. He died in his sleep, surrounded by his family.

In his "testamentary dispositions" Wittlin formulated his wishes with regard to the obsequies. "If I snuff it in New York - I should like a Mass, possibly with some Gregorian chant." But he stipulated "NO 'eulogies.' Let the priest just say a few words about me from the altar." His desires were not taken too strictly to the letter. On Tuesday, $2^{\text {nd }}$ March at 9:45 a.m., Father Henry G. d'Anjou celebrated the funeral rites in the church of St Thomas Moore in Manhattan and delivered his encomium standing by the coffin.

Indeed, we should bury you more nobilium, in a noble manner as Spanish grandees were buried of old. Six El Greco deacons in golden dalmatics should carry your coffin, and six Franciscan friars, lighted paschal candles in hand, kneel by its side. The floor of St Thomas More church should be spread with a carpet of flowers, and your coffin wrapped in the colours of Pope John XXIII. The royal bell

1 Originally published in Konteksty Kultury 2015, vol. 12, no. 4 (the Polish title: "Orfeusz i Kostucha. Ostatnie chwile Józefa Wittlina”). 
of Wawel's cathedral should toll, and the great chorale ring out: "Holy God" . . . "Sanctus Fortis" .... "Hagios Athanatos"!

The next item in Wittlin's testament specifies that he did not wish to be buried "in one of those ghastly, faraway cemeteries. No fancy daubings on my face. The coffin must be closed." Profesor Wiktor Weintraub came from Boston to the funeral which, as he later wrote to Tymon Terlecki, was "very American, for the church was three quarters full, but only four cars followed the hearse to the cemetery. That cemetery, it was the first time I was there, is a specifically American peculiarity: located some 20 miles outside town, vast, and with a rail halt called Walhalla in the middle." After the burial Weintraub offered Halina his assistance in organizing the transfer of Wittlin's manuscripts and correspondence to the Houghton Library at Harvard University, as had been previously agreed.

In his eulogy Father d'Anjou was unable to eschew superlatives, for, as he declared, "no one since the times of Juliusz Słowacki has written in Polish more beautifully and with such perfection as Józef Wittlin." He reminded the gathered mourners of the vicious anti-Semitic attacks directed against Wittlin in the Warsaw press before the war by militant young nationalist writers, "patriots" to the hilt, who "would question whether he belongs to the Polish culture at all." (In hindsight one might surmise that they were also jealous of the fame Wittlin enjoyed in Europe in the late Thirties). Wittlin's situation had not become easier following his conversion to Roman Catholicism. As the preacher made clear:

Even though Joseph Wittlin was the most deeply religious of all Polish twentieth century writers, it was not until he reached New York that he was able to approach the baptismal font. And this only deepened his isolation. It was now: "Leper! Leper! Leper!” from both sides.

And he postulated: "Before the coffin of Joseph Wittlin, Polish Catholicism should fall to its knees and strike its stony breast in penance for its sin of anti-semitism, 'the crime of the just' that calls for the vengeance of heaven. But will it?"

A renowned advocate of Polish-Jewish dialogue and an indefatigable defender of the victims of Nazism, Father Henryk d'Anjou - born in Poland, where he had lived through the German occupation - had more than once provoked the indignant protests of his pious parishioners. At a certain historical moment he had raised the flag of Israel above his church; in fiery sermons he lambasted all symptoms and manifestations of Marxism, nationalism and anti-semitism. In return he received threatening letters. His oration went on:

Last Sunday humanity lost one of the warmest and most fearless champions of such basic decency. This silent coffin holds a passionate cry, the same cry which bursts forth unabated from every page of The Salt of the Earth. The foot soldier Niewiadomski 
ripped from war all the fake jewels in which necrophiles had adorned it, and revealed it in all its horrors. Humanity imbibed the truth about war according to Joseph Wittlin from the millions of copies through which the story was told in many languages. It drank it in but drew no conclusion. Barbusse has called man "the forgetting machine." Joseph Wittlin says that there had awakened in us something like a longing for hell. Until now we all held concealed in our souls a secret nostalgia for the paradise we had lost. Today we know that there are men homesick for hell. And they have taken over the "forgetting machine." And so humanity today does not live, does not exist, but merely marches on. Where to? People drunk with marching never ask.

Wittlin had instructed that the PEN Club of America, the Academy of Darmstadt, the Polish Institute of Arts and Sciences in New York, and Radio Free Europe should all be notified of his demise; there was to be an obituary and photograph in the New York Times. His widow also informed Jerzy Giedroyc, the editor of Kultura in Paris, who, several years previously, had intended to publish a second volume of his works. In a letter to Giedroyc, Czesław Miłosz commented: "The death of Wittlin is like the fable about the shepherd who cried Wolf, and later no one believed him - when I first arrived in New York after the war, he already complained of being over the hill. Unfortunately even hypochondriacs meet their end."

Hypersensitive and highly-strung, Józef Wittlin had suffered poor health for most of his life. Although he was clearly not in good shape at his last literary soirée held in March 1975 at the Kościuszko Foundation, only a few days later at the same venue, speaking from notes, he introduced the New York début of Zofia Romanowicz, the Paris-based novelist whose work he particularly admired. By April, however, a succession of ailments - headaches, vertigo, blurred vision and acute anaemia - meant he was unlikely to take part in the soirée planned for November that year in honour of the late Aleksander Janta-Połczyński. A couple of scrawled sentences are his sole contribution to the book of essays dedicated to Janta's memory; and in the Festschrift for Wiktor Weintraub, Wittlin's name appears only in the Tabula Gratulatoria.

His general condition deteriorated dramatically at the beginning of October - brain ischemia, contusion and inflammation of the synovial were followed by nosebleeds. Then came a fortnight at the university hospital under the care of an empathetic internist from Przemyśl. A series of blood tests revealed an excess of potassium (pointing to uremia) and a sodium deficiency, provoked by reduced activity of the adrenal gland; cortisone was therefore prescribed. Back home in Riverdale, he came down with a severe bout of influenza, followed by a virulent infection and subfebrile state that lasted five weeks. Wittlin was too frail to undergo surgery. During a two-day respite, when the fever abated, he wrote Christmas cards in a shaky hand, reminiscing about school friends, and recalling his youthful years in Lwów, and his early fascination with the poetry of Rilke and the score of Tristan. The anaemia 
persisted; he weighed just 90 pounds. Then the fever returned, with shivers and chattering teeth, and large doses of sulfonamid were applied. By now his voice was noticeably affected.

By the end of January, when the fever hit $40^{\circ}$, Wittlin was back in hospital. Yet, ever haunted by nostalgia for Europe, he could not and would not renounce his old yearnings and longings. As he scribbled in a note: "The skyscrapers at which I stare from my hospital room on the seventeenth floor, desolate by day, are brought to life at night by electric light - they look to me like enormous towering gravestones. The hopelessness of this landscape is saved by the neon advertisement of PAN-AM, like a spark of hope - that I might once more set out across the ocean."

Headed by the friendly doctor from Przemyśl, the entire medical team at the hospital were meanwhile unable to establish a diagnosis, until finally they came up with the formula: F.U.O. - Fever of unknown origin, and attributed its provenance to... a variety of different hypotheses. As Wittlin's half-sister, a distinguished doctor in her own right, put it: "Józio is setting his doctors the toughest of internal medicine exams." Lifelong valetudinarian though he was, Wittlin could not stop for death, so death mustered a veritable cohort of diseases and - kindly stopped for him. One by one his body's organs ceased to function - cirrhosis of the liver had reached a critical state, not to mention necrosis of the cortex, where tumours had developed. For many a decade it had been customary for friends, family, critics, and editors to comment on Wittlin's slow rate of productivity and relatively slender literary output, even as they clamoured for him to complete his trilogy. Known to indulge in monstrous self-pity, complaining in his letters to all and sundry about a seemingly endless litany of complaints, Wittlin was labelled a hypochondriac. The doctors' posthumous verdict told a different story: they opined it was a miracle he had lived at all, let alone grappled with the business of writing. Time perhaps to set the record straight for editors, critics and friends, and do away once and for all with the tired old cliché of Józef Wittlin's imputed hypochondria.

When asked by Giedroyc to write an obituary for Kultura, Czesław Miłosz backed out on the grounds that "basically someone from Lwów should write about Wittlin. Don't you have anyone? Andrzej Vincenz perhaps?” Giedroyc agreed that it might be worth emphasizing the Lemberg connection, "but is young Vincenz up to it? It calls for considerable skill." Giedroyc was admittedly more interested in the unfinished fragments of The Salt of the Earth than in Wittlin's poetry, but "too bad - even the verse will have to be published" a project he never brought to fruition. Finally, in the May issue of Kultura Miłosz penned an unsigned and rather conventional note entitled Farewell to Józef Wittlin: "We bid farewell to Józef Wittlin, a writer ever faithful to his great compassionate love, a man of deep faith, a wise and upright citizen, who for half his life shared the fate of all exiles. At this moment there is no better way of honouring his memory than to present excerpts from his writings." 
So much for Paris. In London the Union of Polish Writers Abroad organized an evening of remembrance. Juliusz Sakowski, doubtless the spiritus movens of the gathering, recalled his long years of friendship with Wittlin, and Bronisław Przyłuski focused on the religious aspects of his poetry. Karol Dorwski and Józef Opieński read fragments from The Salt of the Earth and the translation of the Odyssey. A special issue of Wiadomosici also carried short pieces by Stanisław Baliński, Felix Mantel, Paweł Łysek and Tadeusz Nowakowski. In New York, a farewell evening took place in the late fall, on November $6^{\text {th }}$, under the auspices of the Polish Institute of Arts and Sciences. It was chaired by Zoya Yourieff, the Russian Slavist and author of an English-language monograph on the poet. Other speakers included Wiktor Weintraub, who discussed The Salt of the Earth "with [his] usual critical subtlety," while Tymon Terlecki harked back to personal memories from pre-war Poland, concentrating on the impact of Lwów and its culture on Wittlin's psyche and creativity. In the artistic part Karin Tiche-Falencka recited the lyrical poems he had selected for his last literary evening the previous year. Tola Korian read the poetic Prologue to The Salt of the Earth, excerpts from My Lwów, and "A la recherche du temps perdu," a poem dedicated to her back in the Thirties when she had recited it at concerts in the musical setting by Roman Palester. In the short poem "Postscript to my life," inscribed not long before his death to the pianist Mieczysław Horszowski, Wittlin had prayed that in the afterlife he might be granted the supreme consolation of Wolfgang Amadeus. After a public concert he had given earlier that evening, Horszowski duly arrived at the gathering to perform one of his friend's favourite Mozart sonatas. It was nevertheless Wittlin who had the final word, as the evening closed on a tape of his own voice reading "Hymn upon a Spoon of Soup." According to the note in Wiadomosici - "It was both a voice from beyond the grave, and a testimony of life beyond death."

In the words of one of Wittlin's friends and admirers, "[in his writing] there is not a single untrue word." Halina concurred with this view, as "Józio was constitutionally incapable of telling lies, and that may well have been an obstacle in his writing." A worse impediment perhaps than his perpetual ailments, one might subjoin. 